\title{
Direct Effects of Tamoxifen on Growth Hormone Secretion by Pituitary Cells in vitro
}

\author{
Suzanne A. Malaab, Michael N. Pollak and Cynthia G. Goodyer
}

There is now strong evidence to suggest that insulin-like growth factor I (IGF-I) plays an important role in breast cancer proliferation. Recently we observed that tamoxifen-treated stage I breast cancer patients have serum IGF-I levels significantly lower than placebo-treated patients. Since IGF-I is growth hormone (GH) dependent, we have tested the hypothesis that tamoxifen alters serum IGF-I levels through direct inhibition of GH secretion. Immature lamb pituitary cultures were examined for acute $(3 \mathrm{~h})$ or chronic (1-6 day) effects of the drug, using doses $(0.1-10 \mu \mathrm{mol} / \mathrm{l})$ based on known steady state levels in patients on tamoxifen therapy $(0.31-3.1 \mu \mathrm{mol} / \mathrm{l})$. Tamoxifen had a direct, dose-related, inhibitory effect on $\mathbf{G H}$ release from pituitary somatotropes, during acute as well as chronic treatment. The $10 \mu \mathrm{mol} / \mathrm{l}$ dose consistently decreased both basal and growth hormone releasing factor stimulated GH release. These in vitro data are consistent with our hypothesis that tamoxifen suppresses serum IGF.I levels by acting at the pituitary to inhibit GH release.

\section{INTRODUCTION}

THERE IS now strong evidence to suggest that insulin-like growth factor I (IGF-I) plays an important role in breast cancer [1-5]. Recently, we observed that circulating IGF-I levels were significantly lower in patients with stage I breast cancer on tamoxifen treatment as compared with placebo-treated patients $(0.9$ vs. $1.4 \mathrm{U} / \mathrm{ml} ; P<0.002$ ) [6]. Our study confirmed the preliminary findings from a smaller, non-randomised study $(0.48$ vs. $1.03 \mathrm{U} / \mathrm{ml} ; P<0.01$ ) and supported the suggestion that the anti-neoplastic effects of tamoxifen might be, at least in part, due to suppression of circulating IGF-levels [7].

The mechanism by which tamoxifen, a synthetic nonsteroidal antioestrogen [8], exerts this inhibitory effect is not clear. However, the bulk of the evidence, from clinical as well as experimental studies, indicates that the major influence of oestrogens on serum IGF-I levels is indirect, by modulating

Correspondence to C.G. Goodyer.

C.G. Goodyer is at the Endocrine Research Laboratory, Room C-1238, Montreal Children's Hospital, 2300 Tupper St., Montreal, Quebec, Canada H3H 1P3; C.G. Goodyer and S.A. Malaab are at the Department of Pediatrics; and M.N. Pollak is at the Departments of Oncology and Medicine, McGill University, Montreal, Quebec, Canada. growth hormone (GH) secretion and biological activity [9-13]. Therefore, we decided to test the hypothesis that tamoxifen is suppressing serum IGF-I levels by acting at the level of the pituitary to inhibit $\mathrm{GH}$ release.

Our laboratory has been using cultures of immature lamb pituitary cells to investigate the mechanisms that regulate $\mathrm{GH}$ secretion $[14,15]$. We have chosen this test system to examine both acute and chronic effects of tamoxifen, on basal as well as growth hormone releasing factor (GRF) stimulated and somatostatin inhibited GH release. To determine the specificity of tamoxifen actions, prolactin (PRL) and luteinising hormone (LH) were also assayed. The doses tested $(0.1-10 \mu \mathrm{mol} / \mathrm{l})$ were based on known steady state drug levels in breast cancer patients receiving $20-40 \mathrm{mg}$ of tamoxifen per day $(0.31-3.1 \mu \mathrm{mol} / \mathrm{l})$ [16].

Materials

\section{MATERIALS AND METHODS}

Collagenase (Type IV) was purchased from Cooper Biomedical (Mississauga, Ont., Canada), DNase from the Sigma Chemical Co. (St Louis, Missouri), 24-well $\left(2 \mathrm{~cm}^{2}\right)$ tissue culture plates and Ham's F-10 culture medium from Flow Laboratories, Inc. (Mississauga, Ontario, Canada), defined fetal bovine serum (FBS) from Hyclone Sterile Systems (Logan, Utah), penicillin- 
G from Ayerst (Montreal, Quebec, Canada), gentamycin from Schering (Pointe-Claire, Quebec, Canada), and fungizone from Squibb (Montreal, Quebec, Canada). Growth hormone releasing factor (hGRF ${ }^{1-44}$ ) and somatostatin ${ }^{1-14}$ were obtained from Peninsula Laboratories (Belmont, California). Tamoxifen citrate (trans isomer only) was a gift from ICI Pharmaceuticals (Macclesfield, Cheshire, UK).

\section{Cell cultures}

Anterior pituitary glands were collected from 21-33 day old immature male lambs (mixed breed: Suffolk/Dorset/Hampshire) following anesthesia with $50 \mathrm{mg} / \mathrm{kg}$ of ketamine and exsanguination. These protocols were in accordance with CCAC guidelines and had approval from the McGill University Animal Care Committee. Individual glands were minced with sterile scissors and dispersed enzymatically using collagenase and DNase [14, 15]. Monolayer cultures (100,000 cells/well.ml) were incubated at $37^{\circ} \mathrm{C}$ in a humidified atmosphere containing $5 \% \mathrm{CO}_{2}$ for $72 \mathrm{~h}$ before experiments were begun. The culture medium (Ham's F10 supplemented with $10 \%$ heat-inactivated FBS and antibiotics $(200 \mathrm{U} / \mathrm{ml}$ penicillin, $5 \mu \mathrm{g} / \mathrm{ml}$ fungizone and $32 \mu \mathrm{g} / \mathrm{ml}$ gentamycin) was changed daily beginning on the second day of culture. This medium contained $\leqslant 1.5 \mathrm{pg}$ of oestrogens (oestradiol + oestrone) and $\leqslant 3.5 \mathrm{pg}$ of androgens (testosterone + androstenedione) per $\mathrm{ml}$. The phenol red concentration was $3.1 \mathrm{nmol} / \mathrm{ml}$.

\section{Experimental protocols}

The ovine pituitary cells were examined for acute effects of tamoxifen on basal as well as GRF-stimulated and somatostatininhibited GH secretion, basal PRL and basal LH release. 3, 6 or 9 days after the cultures were established, the cells were preincubated for $1 \mathrm{~h}$ in culture medium, washed and then incubated for $3 \mathrm{~h}$ at $37^{\circ} \mathrm{C}$ in culture medium supplemented with varying concentrations of tamoxifen $(0.1-10 \mu \mathrm{mol} / \mathrm{l})$ or the equivalent volume of diluent (methanol) and $1 \mathrm{nmol} / \mathrm{l} \mathrm{GRF}$, $100 \mathrm{nmol} / 1$ somatostatin or a combination of the two hypothalamic regulatory peptides. Previous studies using this test model had shown that these doses of GRF and somatostatin had maximal stimulatory and inhibitory effects, respectively, on GH release $[14,15]$.

Cultures were also tested for chronic effects of tamoxifen using a 3 or 6 day treatment protocol (on days 3-6 or 9 in vitro). Media were collected and changed every $24 \mathrm{~h}$, and test solutions (culture medium supplemented with $0.1-10 \mu \mathrm{mol} / \mathrm{l}$ tamoxifen or equivalent concentrations of the diluent) were made up fresh daily. At the end of the 3 or 6 days of pretreatment, the cultures were rinsed and preincubated in culture medium alone for $1 \mathrm{~h}$, then rinsed and incubated for $3 \mathrm{~h}$ at $37^{\circ} \mathrm{C}$ in culture medium to which $1 \mathrm{nmol} / 1 \mathrm{GRF}, 100 \mathrm{nmol} / 1$ somatostatin or a combination of the two peptides had been added.

Each experimental group was tested in triplicate or quadruplicate; all of the acute and chronic series of experiments were carried out using 3-6 different preparations of pituitary cells, with final results calculated from the means of the repeat experiments. Media samples were collected, centrifuged for $10 \mathrm{~min}$ at $3000 \mathrm{rpm}$ at $4^{\circ} \mathrm{C}$ and the supernatants were kept frozen at $-20^{\circ} \mathrm{C}$ until assayed for ovine $\mathrm{GH}$ and, in certain cases, for ovine PRL and $\mathrm{LH}$ as well. Cell cultures were rinsed with cold phosphate-buffered saline and then frozen at $-20^{\circ} \mathrm{C}$ until representative wells were processed for DNA and protein determinations.
Table 1. Effect of tamoxifen during $3 h$ basal $L H, G H$ and PRL secretion

\begin{tabular}{rccc}
\hline & LH & GH & PRL \\
\hline $\begin{array}{l}\text { Control (with or without } \\
\text { diluent })\end{array}$ & $0.31(0.03)^{*}$ & $23.4(1.5)$ & $31.8(2.7)$ \\
$\begin{array}{r}\text { Tamoxifen }(0.1 \mu \mathrm{mol} / \mathrm{l}) \\
(1 \mu \mathrm{mol} / \mathrm{l})\end{array}$ & $0.31(0.03)$ & $24.7(3.0)$ & $28.0(2.1)$ \\
$(10 \mu \mathrm{mol} / \mathrm{l})$ & $0.28(0.01)$ & $22.9(3.5)$ & $21.1(2.5) \dagger$ \\
\hline
\end{tabular}

* Data are expressed as $\mathrm{ng} / \mathrm{ml}$, mean (S.D.), $n=4$ wells/experimental group.

$+P<0.01$ : statistical significance as compared to controls (with or without diluent).

\section{Ovine $G H, L H$ and PRL radioimmunoassays}

Ovine GH, LH and PRL were measured in duplicate by specific double antibody radioimmunoassays (RIA) $[14,15,17]$. Reagents were kindly provided by the National Hormone and Pituitary Program (NIDDK, Bethesda, Maryland) with the exception of the primary antibody for oPRL (\#AR1.6) which was a gift from Dr H. Friesen (Winniepeg, Manitoba, Canada) [17]. The sensitivity of the assays was $0.4 \mathrm{ng}(\mathrm{oGH}-\mathrm{I}-4) / \mathrm{ml}$, $0.2 \mathrm{ng}(\mathrm{NIH}-\mathrm{P}-\mathrm{S} 12) / \mathrm{ml}$ and $0.15 \mathrm{ng}(\mathrm{NIH}-\mathrm{LH}-\mathrm{S} 24) / \mathrm{ml}$. Interassay variation was 5,7 and $6 \%$, respectively. Representative samples were prescreened at several dilutions, to test for parallelism to the standard curve, and then all samples from a specific experiment were run in the same assay at the appropriate dilution.

\section{DNA and protein determinations}

Four wells of cells were scraped and pooled for each determination of DNA and protein. The DNA was measured according to the method described by Erwin et al. [18] while the protein content was assayed using the method of Lowry et al. [19].

\section{Expression of the results}

GH, PRL and LH results are expressed as nanograms per $\mathrm{ml}$ of culture medium (Tables 1 and 2) or as a per cent of the appropriate control values (Figs 1-6); by normalising the data as a per cent of control, the results of several repeat experiments could be pooled. Because basal hormone secretion was not altered by the presence of diluent in the medium, all control (with or without diluent) data were pooled for each experiment prior to statistical analysis. DNA and protein results were expressed as $\mu \mathrm{g} / 4$ wells. GH, PRL and LH data were statistically analysed using analysis of variance (ANOVA) followed by Duncan's multiple range test after logarithmic transformation.

\section{RESULTS \\ Acute effects of tamoxifen on $G H$}

During acute $(3 \mathrm{~h})$ exposure of the pituitary somatotropes to increasing concentrations of tamoxifen $(0.1-10 \mu \mathrm{mol} / \mathrm{l})$, there was a dose-related inhibition of basal GH secretion (Fig. 1). The decrease was always significant $(P<0.01)$ for the highest dose tested $(10 \mu \mathrm{mol} / 1) ; 1 \mu \mathrm{mol} / 1$ tamoxifen caused a significant inhibition $(P<0.01)$ during one of four experiments, while $0.1 \mu \mathrm{mol} / 1$ tamoxifen did not alter basal $\mathrm{GH}$ release.

$10 \mu \mathrm{mol} / 1$ tamoxifen also significantly inhibited the $\mathrm{GH}$ response to $1 \mathrm{nmol} / \mathrm{l} \mathrm{GRF}$ during an acute $(3 \mathrm{~h}$ ) incubation: there was a $69 \%$ decrease relative to the control-GRF group $(P<0.01)$ (Fig. $2 ; n=4$ experiments). The lower doses of 
Table 2. Effect of chronic treatment with tamoxifen on 24 secretion of (a) $L H,(b) G H$, and (c) PRL

\begin{tabular}{|c|c|c|c|}
\hline & \multicolumn{3}{|c|}{ Time (h) } \\
\hline & 0 & 72 & 144 \\
\hline \multicolumn{4}{|l|}{ (a) LH } \\
\hline $\begin{array}{l}\text { Control (with or without } \\
\text { diluent) }\end{array}$ & $1.40(0.11)^{*}$ & $0.60(0.06)$ & $0.49(0.07)$ \\
\hline $\begin{array}{l}\text { Tamoxifen }(1 \mu \mathrm{mol} / \mathrm{l}) 144 \mathrm{~h} \\
\text { Tamoxifen }(1 \mu \mathrm{mol} / \mathrm{l}) \\
72 \mathrm{~h} / \mathrm{Con} 72 \mathrm{~h}\end{array}$ & $\begin{array}{l}1.45(0.19) \\
1.59(0.19)\end{array}$ & $\begin{array}{l}0.64(0.08) \\
0.70(0.05)\end{array}$ & $\begin{array}{l}0.46(0.04) \\
0.48(0.01)\end{array}$ \\
\hline $\begin{array}{l}\text { Tamoxifen }(10 \mu \mathrm{mol} / \mathrm{l}) 144 \mathrm{~h} \text { : } \\
\text { Tamoxifen }(10 \mu \mathrm{mol} / \mathrm{l}) \\
72 \mathrm{~h} / \mathrm{Con} 72 \mathrm{~h}\end{array}$ & $\begin{array}{ll}1.51 & (0.12) \\
1.57 & (0.18)\end{array}$ & $\begin{array}{l}0.36(0.02) \dagger \\
0.37(0.02) \dagger\end{array}$ & $\begin{array}{l}0.32(0.03) \dagger \\
0.45(0.05)\end{array}$ \\
\hline \multicolumn{4}{|l|}{ (b) $\mathrm{GH}$} \\
\hline $\begin{array}{l}\text { Control (with or without } \\
\text { diluent) }\end{array}$ & $236(28)$ & $127(20)$ & $49(6)$ \\
\hline $\begin{array}{l}\text { Tamoxifen }(1 \mu \mathrm{mol} / \mathrm{l}) 144 \mathrm{~h} \\
\text { Tamoxifen }(1 \mu \mathrm{mol} / \mathrm{l}) \\
72 \mathrm{~h} / \mathrm{Con} 72 \mathrm{~h}\end{array}$ & $\begin{array}{l}227(21) \\
236(12)\end{array}$ & $\begin{array}{l}132(17) \\
130(2)\end{array}$ & $\begin{array}{l}51(4) \\
50(8)\end{array}$ \\
\hline $\begin{array}{l}\text { Tamoxifen }(10 \mu \mathrm{mol} / 1) 144 \mathrm{~h} \\
\text { Tamoxifen }(10 \mu \mathrm{mol} / \mathrm{l}) \\
72 \mathrm{~h} / \operatorname{Con} 72 \mathrm{~h}\end{array}$ & $\begin{array}{l}250(11) \\
254(4)\end{array}$ & $\begin{array}{l}31(6) \dagger \\
31(1) \dagger\end{array}$ & $\begin{array}{l}25(2) \dagger \\
47(4)\end{array}$ \\
\hline \multicolumn{4}{|l|}{ (c) PRL } \\
\hline $\begin{array}{l}\text { Control (with or without } \\
\text { diluent) }\end{array}$ & $217(13)$ & $192(18)$ & $111(22)$ \\
\hline $\begin{array}{l}\text { Tamoxifen }(1 \mu \mathrm{mol} / \mathrm{l}) 144 \mathrm{~h} \\
\text { Tamoxifen }(1 \mu \mathrm{mol} / \mathrm{l}) \\
72 \mathrm{~h} / \mathrm{Con} 72 \mathrm{~h}\end{array}$ & $\begin{array}{l}248(24) \\
233(21)\end{array}$ & $\begin{array}{l}131(6) \dagger \\
140(8) \dagger\end{array}$ & $\begin{array}{l}53(6) \dagger \\
96(5) \dagger\end{array}$ \\
\hline $\begin{array}{l}\text { Tamoxifen }(10 \mu \mathrm{mol} / \mathrm{l}) \mathrm{l} 44 \mathrm{~h} \\
\text { Tamoxifen }(10 \mu \mathrm{mol} / \mathrm{l}) \\
72 \mathrm{~h} / \mathrm{Con} 72 \mathrm{~h}\end{array}$ & $\begin{array}{l}212(19) \\
216(8)\end{array}$ & $\begin{array}{l}<14.5 t \\
<14.5 t\end{array}$ & $\begin{array}{l}<14.5 \dagger \\
65(7) \dagger\end{array}$ \\
\hline
\end{tabular}

* Data are expressed as $\mathrm{ng} / \mathrm{ml}$, mean (S.D.), $n=4$ wells/experimental group.

† $P<0.01$ : statistical significance as compared to controls (with or without diluent).

tamoxifen $(0.1$ or $1 \mu \mathrm{mol} / \mathrm{l})$ had no consistent effect (data not shown).

$100 \mathrm{nmol} / 1$ somatostatin caused a $30 \%$ decrease in $3 \mathrm{~h} \mathrm{GH}$ secretion under control (with or without diluent) conditions; none of the tamoxifen doses significantly altered this inhibitory effect (Fig. 2; data not shown). While the data in Fig. 2 (as well as in later figures) suggest that $10 \mu \mathrm{mol} / \mathrm{l}$ tamoxifen had the tendency to block the actions of somatostatin, these results reflect the fact that the data are expressed as experimental values over their respective controls: this high dose of tamoxifen exerts, by itself, a maximal inhibitory effect on basal GH release (Fig. 1).

The $10 \mu \mathrm{mol} / 1$ dose of tamoxifen also appears to be maximally inhibitory for GRF-stimulated GH release; when $10 \mu \mathrm{mol} / 1$ tamoxifen was added in the presence of both GRF and somatostatin, the decrease in GH secretion was not significantly different from that observed with GRF alone (Fig. 2). As a result, the apparently significant $(P<0.05)$ difference between the two

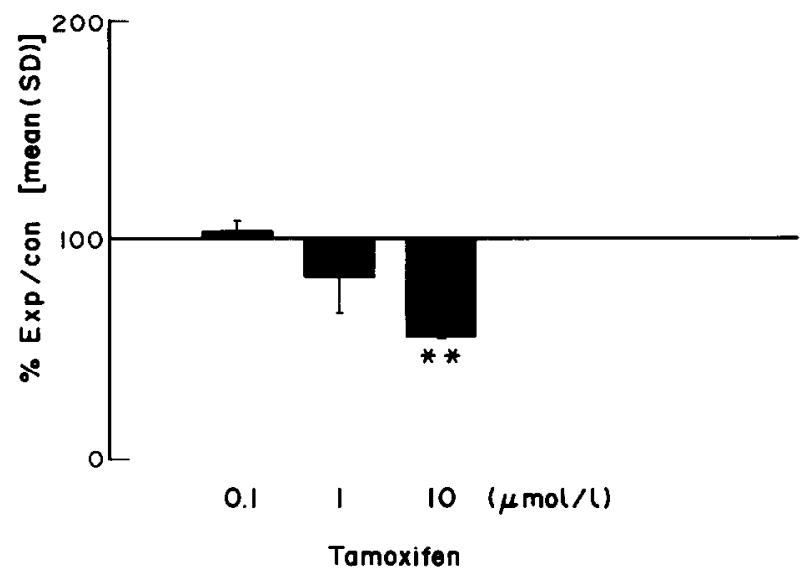

Fig. 1. Acute effects of tamoxifen on basal somatotrope activity. Results are expressed as a ratio of $\mathbf{G H}$ released during tamoxifen treatment (exp) over that released during control (with or without diluent) conditions (con). $* * P<0.01$ as compared with the control (con/con) group of data.

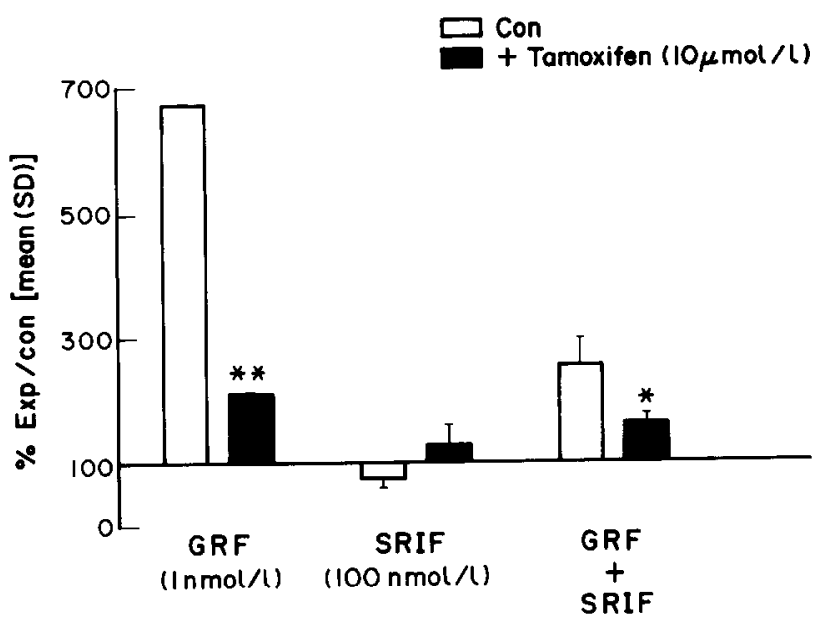

Fig. 2. Acute effects of tamoxifen during $3 \mathrm{~h} \mathrm{GRF-stimulated} \mathrm{and/or}$ somatostatin-inhibited GH release. Results are expressed as a per cent of their respective control (with or without $10 \mu \mathrm{mol} / \mathrm{l}$ tamoxifen). $* P<0.05, * * P<0.01$ as compared with the tamoxifen-untreated (open bar) group. SRIF = somatostatin.

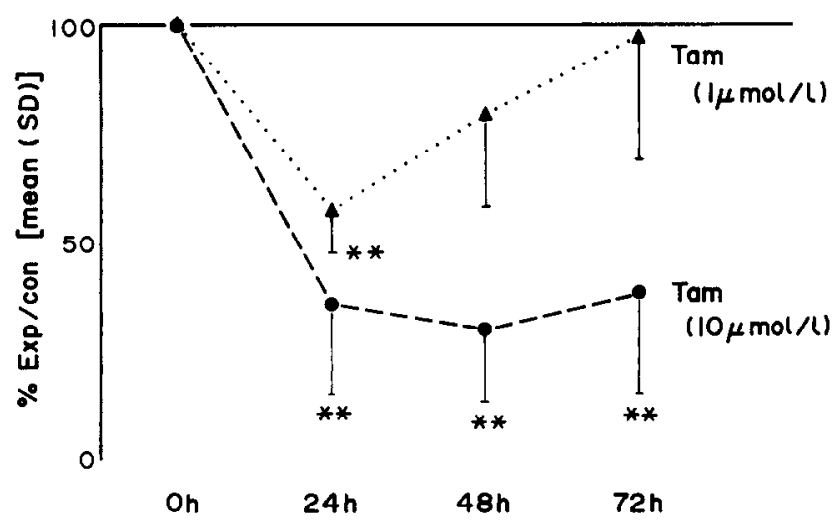

Fig. 3. GH secretion during $72 \mathrm{~h}$ exposure to tamoxifen. Results are expressed as a per cent of control GH secretion during the same $24 \mathrm{~h}$ period. ${ }^{* *} P<0.01$ as compared with the tamoxifen-untreated group. 


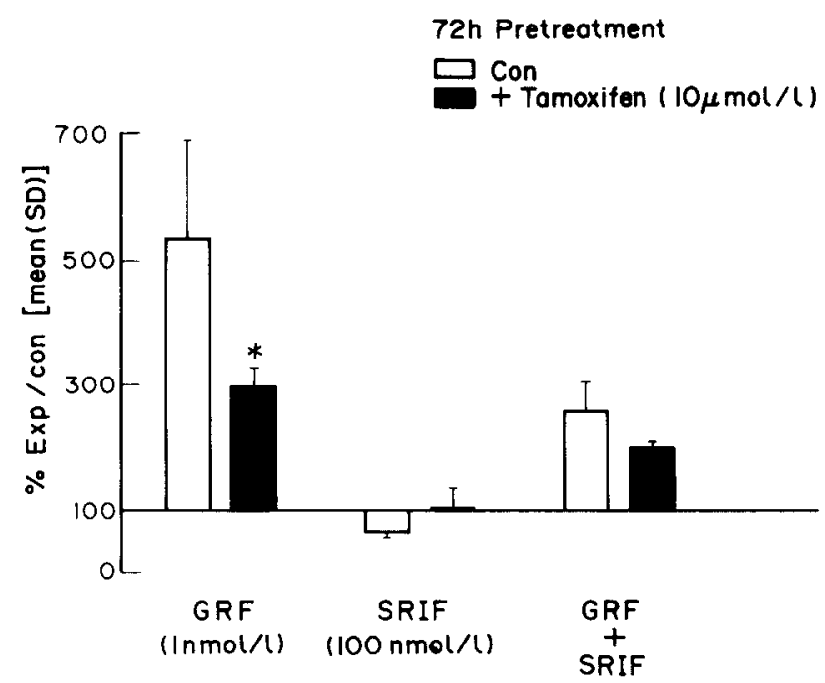

Fig. 4. Effect of $72 \mathrm{~h}$ of pretreatment with tamoxifen on subsequent 3 h GRF-stimulated and/or SRIF-inhibited GH release. Results are expressed as a per cent of their respective control (with or without pretreatment with tamoxifen). $* P<0.05$ as compared with the tamoxifen-untreated (open bar) group.

GRF plus somatostatin groups due to tamoxifen treatment is not of physiological importance (Fig. 2).

\section{Chronic effects of tamoxifen on $G H$}

Chronic exposure of the somatorropes to tamoxifen caused a dose-related decrease in daily GH secretion (Fig. $3 ; n=6$ experiments). The inhibition was significant for the $10 \mu \mathrm{mol} / 1$ dose over a $1-6$ day period $[35.8(19.1) \%$ mean (S.D.) of control; $P<0.01]$ (Figs 3 and 5 ; data not shown). $1 \mu \mathrm{mol} / \mathrm{l}$ tamoxifen consistently decreased GH release for the first $24 \mathrm{~h}[57.7(10.0)$; $P<0.01$ ]; however, by $48 \mathrm{~h}$ its action was less pronounced and by $72 \mathrm{~h}$ basal secretion had returned to control values (Fig. 3). $0.1 \mu \mathrm{mol} / \mathrm{l}$ tamoxifen had no significant effect at any of the time points examined.

Following $72 \mathrm{~h}$ incubation with $10 \mu \mathrm{mol} / 1$ tamoxifen, there was a significant decrease in the subsequent $3 \mathrm{~h}$ basal [67 (6)\% of control; $P<0.01$ ] as well as $1 \mathrm{nmol} / \mathrm{l} \mathrm{GRF}$-stimulated secretion of $\mathrm{GH}(P<0.05)$ (Fig. $4 ; n=3$ experiments). As observed previously, during the acute treatment experiments,

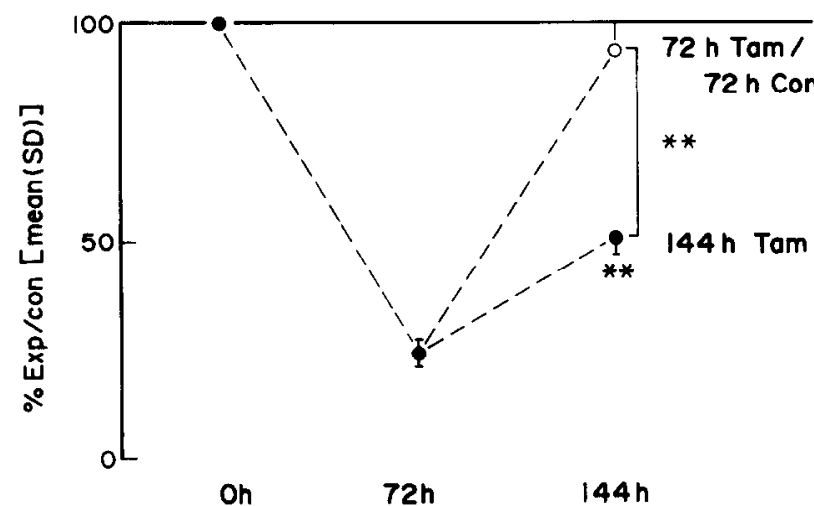

Fig. 5. GH secretion during either continuous exposure to tamoxifen over $144 \mathrm{~h}$ or $72 \mathrm{~h}$ exposure to tamoxifen followed by $72 \mathrm{~h}$ in control medium. Results are expressed as a per cent of control GH secretion during the same $24 \mathrm{~h}$ period. ** $P<0.01$ as compared with the tamoxifen-untreated group. $\neg * * P<0.01$, statistical difference between the two experimental groups.

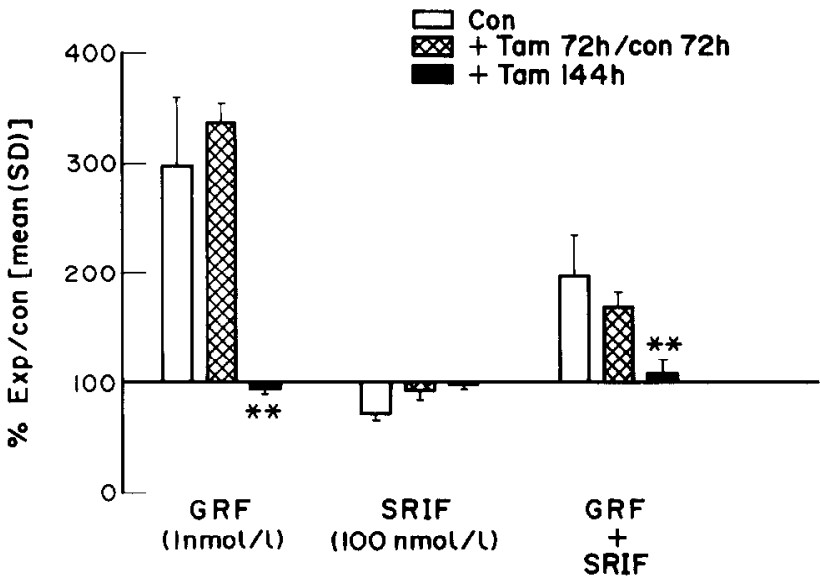

Fig. 6. $3 \mathrm{~h}$ GRF-stimulated and/or somatostatin-inhibited GH release following: (1) 144 h pretreatment with tamoxifen (solid bars) or (2) $72 \mathrm{~h}$ pretreatment with tamoxifen followed by $72 \mathrm{~h}$ in control medium (hatched bars). Results are expressed as a per cent of their respective control (with or without pretreatment with tamoxifen). $* * \boldsymbol{P}<0.01$ as compared with the tamoxifen-untreated (open bar) group.

there was no significant change in the somatotropes response to $100 \mathrm{nmol} / \mathrm{l}$ somatostatin. Also, pretreatment with the two lower doses of tamoxifen had no consistent effect on the subsequent $3 \mathrm{~h}$ basal, GRF-stimulated or somatostatin inhibited $\mathrm{GH}$ release (data not shown).

In one experiment, cultures were treated with $10 \mu \mathrm{mol} / \mathrm{l}$ tamoxifen for $72 \mathrm{~h}$ and then divided into two experimental groups: one set continued to be treated with $10 \mu \mathrm{mol} / \mathrm{l}$ tamoxifen for a further $72 \mathrm{~h}$, while the second set was placed in control medium for $72 \mathrm{~h}$, to determine whether the cells could recover from the drug treatment (Fig. $5 ; n=1$ experiment). These groups underwent a $3 \mathrm{~h}$ test with GRF with or without somatostatin following the first $72 \mathrm{~h}$, and again following the second 72 h (Fig. 6).

In those cultures that were treated with $10 \mu \mathrm{mol} / \mathrm{l}$ tamoxifen for a total of $144 \mathrm{~h}$, daily GH secretion continued to be markedly suppresed $(P<0.01)$ (Fig. 5). In addition, response to $1 \mathrm{nmol} / \mathrm{l}$ GRF was now completely blocked $(P<0.01$ ) (Fig. 6, solid bars). The chronic tamoxifen treatment again had no significant effect on somatostatin (Fig. 6).

Those cultures exposed to $10 \mu \mathrm{mol} / 1$ tamoxifen for $72 \mathrm{~h}$ followed by $72 \mathrm{~h}$ in control medium showed a total recovery of daily basal GH secretion (Fig. 5). In addition, there was complete recovery of a subsequent $3 \mathrm{~h}$ response to $1 \mathrm{nmol} / \mathrm{l} \mathrm{GRF}$ alone or the combination of GRF plus somatostatin (Fig. 6).

\section{Acute and chronic effects of tamoxifen on ovine PRL}

Tamoxifen had profound dose-related, inhibitory effects on lactotrope function in this test system. Both the 1 and $10 \mu \mathrm{mol} / \mathrm{l}$ doses significantly decreased PRL release under acute (Table 1; $n=1$ experiment) as well as chronic (Table $2 ; n=1$ experiment) conditions; the $10 \mu \mathrm{mol} / 1$ dose suppressed PRL secretion to below RIA detectability after 3 and 6 days of exposure. When cultures were allowed to recover for $72 \mathrm{~h}$ following $72 \mathrm{~h}$ of tamoxifen treatment (Table 2), lactotrope activity returned to control values only in those cultures pretreated with the $1 \mu \mathrm{mol} / 1$ dose of tamoxifen; those cells pretreated with the $10 \mu \mathrm{mol} / 1$ dose continued to secrete PRL at a rate significantly lower than the controls $(P<0.01)$. 
Acute and chronic effects of tamoxifen on ovine $L H$

The gonadotropes were relatively unaffected by exposure to tamoxifen. LH release remained unchanged during acute tests (Table 1), while only the highest dose of the anti-oestrogen significantly inhibited $\mathrm{LH}$ following chronic treatment $(P<0.01)$ (Table 2). Those cells allowed to recover from $72 \mathrm{~h}$ exposure to $10 \mu \mathrm{mol} / \mathrm{l}$ tamoxifen returned to control $\mathrm{LH}$ values (Table 2)

\section{Chronic effects of tamoxifen on DNA and protein}

None of the doses of tamoxifen tested had any significant effect on cell DNA or protein following chronic ( 3 or 6 day) treatment. Control cultures had $7.4(1.9) \mu \mathrm{g}$ DNA and 127 (18) $\mu \mathrm{g}$ protein $/ 4$ wells ( $n=3$ experiments); cultures treated with $0.1-10 \mu \mathrm{mol} / 1$ tamoxifen had 8.9 (3.2) $\mu \mathrm{g}$ DNA and 174 (38) $\mu \mathrm{g}$ protein $/ 4$ wells.

\section{DISCUSSION}

Tamoxifen is an effective hormonal agent in both adjuvant and palliative treatment of breast cancer $[1,20]$. The classic mechanism of action of this drug is thought to involve a blockade of oestrogen receptors in tumour cells $[8,21]$. However, our investigations suggest that tamoxifen may also be reducing tumour growth through suppression of the GH-IGF-I axis: (1) tamoxifen inhibits both basal and GRF-stimulated GH release from pituitary cells (present study); (2) serum levels of (GH-dependent) IGF-I are lower in breast cancer patients receiving tamoxifen than those receiving placebo [6]; and (3) inhibition of IGF activity at the level of the breast cancer cell is associated with decreased growth of the mammary tumour [3]. Thus, tamoxifen may decrease proliferation of breast cancer cells both directly, at the tumour level, and indirectly, by suppressing pituitary somatotrope function.

Our present experimental model is one that we have been using for several years to study mechanisms that regulate $\mathrm{GH}$ secretion. It is similar to the system established by Jordan and his colleagues to do comparative testing of anti-oestrogens in that it consists of primary monolayer cultures of immature pituitary cells; our source is the lamb while they use the rat [8, $14,15]$. One major difference between these two test models, besides the obvious one of species, is that we have made no attempt to remove oestrogens from the culture environment. Our goal in this initial series of experiments was to determine whether tamoxifen could modulate $\mathrm{GH}$ secretion under conditions that were as physiological as possible, not to determine the exact mechanism(s) by which tamoxifen might exert its effects.

In our test system, tamoxifen suppressed basal somatotrope activity following both acute and chronic exposure, indicating that this drug may interfere with mechanisms that regulate hormone synthesis as well as secretion. In addition, the antioestrogen may be down-regulating the GRF receptor or at least compromising its functional activity: the longer the pretreatment period, the greater the inhibitory effect of the $10 \mathrm{umol} / 1$ dose of tamoxifen on somatotrope responsivness to GRF.

In contrast, tamoxifen did not appear to enhance the inhibitory effects of somatostatin on basal or GRF-stimulated GH release. It is possible, however, that if we were to change the test conditions and use a lower than maximal dose of somatostatin as well as doses of tamoxifen between $1 \mu \mathrm{mol} / \mathrm{l}$ (that gave an inconsistent inhibition) and $10 \mu \mathrm{mol} / \mathrm{l}$ (that gave a maximal inhibition), we might observe an interaction between these two inhibitory factors. This possibility is of importance in light of a recent suggestion that the combination of tamoxifen and a longacting somatostatin analogue be evaluated in clinical trials of breast cancer patients $[6,22]$. Previous proposals to test the efficacy of somatostatin analogues have been based on the finding of somatostatin receptors in a population of breast cancers, as well as on studies showing that somatostatin has direct antiproliferative effects on tumor cells $[23,24]$. Since IGF-I is a potent mitogen for breast cancer, the reduction in IGF-I levels seen with somatostatin analogues [25] or anti-oestrogen treatment $[6,7]$ may be therapeutically relevant; and a combined anti-oestrogen and somatostatin treatment may reduce IGF-I levels further than is observed with either agent alone.

It is unlikely that the suppressive effects of tamoxifen on pituitary cell function were secondary to drug cytotoxicity. There was a significant inhibition of both GH and PRL secretion within as short a period of exposure as $3 \mathrm{~h}$. Moreover, even after 6 days of treatment, those cclls incubated with the highest dose $(10 \mu \mathrm{mol} / \mathrm{l})$ of tamoxifen had the same morphological appearance under phase microscopy as cells in control medium and there were no significant changes in culture DNA or protein levels. In addition, $72 \mathrm{~h}$ following $10 \mu \mathrm{mol} / \mathrm{l}$ tamoxifen withdrawal, secretion of $\mathrm{GH}$ and $\mathrm{LH}$ had returned to normal while PRL release showed almost $60 \%$ recovery. Also, tamoxifen scemed to have a differential rather than global effect on the three pituitary cell types, the lactotropes being more susceptible than somatotropes, and both were more sensitive than the gonadotropes.

The most effective concentration of tamoxifen in our system was $10 \mu \mathrm{mol} / 1$ : this dose consistently inhibited both basal and stimulated somatotrope activity. Evidence that such an effect has biological significance includes: (1) this is only three times the highest steady state serum level observed in patients on chronic tamoxifen therapy [16]; and (2) unlike under in vivo conditions, in our cultures there is probably no transformation of the tamoxifen to its 10 -fold more potent metabolite, 4-hydroxy tamoxifen [8].

Whether tamoxifen is inhibiting somatotrope activity by binding to oestrogen receptors can not be concluded from our experimental protocols since we did not compare tamoxifen actions in the presence versus absence of oestrogens. Certainly, oestrogen receptors have been identified on somatotropes [13] and there are a large number of clinical as well as experimental data to support the concept that sex steroids, especially oestrogens, are an important physiological modulator of GH secretion. Both spontaneous as well as stimulated $\mathrm{GH}$ peak levels increase during puberty and decrease after the second decade, while postpubertal females have higher mean serum GH concentrations than age-matched males; these changes in somatotrope activity are strongly correlated with circulating levels of oestrogens but not testosterone, PRL or cortisol [9]. In addition, changes in the gonadal steroid environment, due to pharmacological manipulation, results in parallel changes in $\mathrm{GH}$ secretion $[10,11]$. Similar data have been reported from animal studies, including both indirect in vivo and direct in vitro experiments $[12,13]$.

Despite the fact that $\mathrm{GH}$ has been implicated in breast tumour growth, its functional role is not clearly understood [1]. In vivo experiments have shown that high doses of GH can influence mammary growth and tissue IGF-I levels in oestrogen-treated animals, but a direct GH-induced mitogenic effect has been difficult to demonstrate under in vitro test conditions $[1,26]$. GH receptors have been identified in several breast cancer cell lines and, more recently, mRNA for the GH receptor was 
localised to the alveolar epithelial cells of the normal bovine mammary gland; however, binding studies using tissue membranes have revealed little to no specific GH binding [1, 27]. Thus, published data suggest that the major physiological role for GH is via regulation of hepatic IGF-I production and circulating IGF-I levels.

IGF-I is considered to be a potent mitogen for breast tumour cells $[1-3,5]$. Recent data suggest that both serum and local tissue IGF-I may be involved in breast cancer growth; tumour tissues contain IGF-I mRNA and, using in situ hybridisation techniques, this mRNA has been localised to the mammary stromal (but not normal or malignant epithelial) cells [4]. What influences this local production of IGF-I is not yet known. However, it is clear, from in vivo as well as in vitro experiments, that inhibition of IGF-I biologic activity (by blocking the Type I IGF receptor) results in decreased mammary tumour growth [5]. Therefore, decreasing circulating as well as local tissue production of IGF-I may offer an important new therapeutic strategy for breast cancer.

In summary, our in vitro studies demonstrate that tamoxifen has direct effects on pituitary function, inhibiting GH, PRL and, to a lesser extent, $\mathrm{LH}$ secretion. These data, in combination with the results of our clinical investigations, suggest that tamoxifen may exert its anti-neoplastic effect by suppressing the pituitary-IGF-I axis as well as by blocking oestrogen receptors directly on the tumour cells. Further experiments are needed to determine whether: (1) tamoxifen decreases somatotrope activity through an oestrogen or a non-oestrogen receptor pathway, (2) tamoxifen alters GH synthesis as well as secretion, and (3) tamoxifen modulates somatotrope responsiveness to GRF at the GRF receptor or a secondary intracellular level.

1. Lippman ME, Dickson RB. Mechanism of growth in normal and malignant breast epithelium. Rec Prog Horm Res 1989, 45, 383-440.

2. Cullen KJ, Yee W, Sly WS, et al. Insulin-like growth factor receptor expression and function in human breast cancer. Cancer Res 1990, 50, 48-53.

3. Pollak MN, Polychronakos C, Tousefi S, Richard M. Characterization of insulin-like growth factor I (IGF-I) receptors of human breast cancer cells. Biochem Biophys Res Comm 1988, 154, 326-331.

4. Yee D, Soonmyoung P, Lebovic GS, et al. Analysis of insulin-like growth factor I gene expression in malignancy: evidence for a paracrine role in human breast cancer. Mol Endocrinol 1989, 3, 509-517.

5. Arteaga CL, Kitten LJ, Coronado EB, et al. Blockade of the Type I somatomedin receptor inhibits growth of human breast cancer cells in athymic mice. 7 Clin Invest 1989, 84, 1418-1423.

6. Pollak MN, Costantino J, Polychronakos C, et al. Effects of tamoxifen on serum insulin-like growth factor I levels of stage I breast cancer patients. $\mathcal{F} N C I 1990,82,1693-1697$.

7. Colleti RB, Roberts JD, Devlin JT, Copeland C. Effects of tamoxifen on plasma insulin-like growth factor I in patients with breast cancer. Cancer Res 1989, 49, 1882-1884.

8. Jordan VC, Koch R, Langan S, McCague R. Ligand interaction at the estrogen receptor to program anticstrogen action: a study with nonsteroidal compounds in vitro. Endocrinology 1988, 122 1449-1454.

9. Ho KY, Evans WS, Blizzard RM, et al. Effects of sex and age on the 24-hour profile of growth hormone secretion in man: importance of endogenous estradiol concentrations. $\mathcal{f}$ Clin Endocrinol Metab $1987,64,51-58$

10. Mansfield MJ, Rudlin CR, Crigler JF, et al. Changes in growth and serum growth hormone and plasma somatomedin-C levels during suppression of gonadal sex steroid secretion in girls with central precocious puberty. F Clin Endocrinol Metab 1988, 66, 3-9.

11. Frohlander N, von Schoultz B. Growth hormone and somatomedin
C during postmenopausal replacement therapy with oestrogen alone and in combination with an antioestrogen. Maturitas 1988, 9, 297-302.

12. Jansson JO, Eden S, Isaksson O. Sexual dimorphism in the control of growth hormone secretion. Endo Rev 1985, 6, 128-150.

13. Shirasu $K$, Stumpf WE, Sar M. Evidence for direct action of estradiol on growth hormone-releasing factor (GRF) in rat hypothalamus: localization of [3-H] estradiol in GRF neurons. Endocrinology 1990, 127, 334-349.

14. Blanchard MM, Goodyer CG, Charrier J, Dulor JP, Barenton B. Effects of hypothalamic hormones (GRF, TRH, somatostatin) and insulin-like growth factor I on growth hormone secretion from prepubertal male lamb pituitary cultures. Reprod Nurr Develop $1987,27,471-480$

15. Blanchard MM, Goodyer CG, Charrier J, Barenton B. In vitro regulation of growth hormone $(\mathrm{GH})$ release from ovine pituitary cells during fetal and neonatal development: effects of GH-releasing factor, somatostatin, and insulin-like growth factor I. Endocrinology $1988,122,2114-2120$.

16. Patterson JS, Settatree RS, Adam HK. Serum concentrations of tamoxifen and major metabolite during longterm Nolvadex therapy: correlation with clinical response. In: Mourisden JT, Palshif T, eds. Breast Cancer-Experimental and Clinical Aspects, Oxford, Pergamon Press, 1980, 89-92.

17. Sanford LM, Beaton DB, Howland BE, Palmer WM. Photoperiodinduced changes in luteinizing hormone, follicle-stimulating hormone, prolactin and testosterone secretion in the ram. Can f Anim Sci 1978, 58, 123-128.

18. Erwin BD, Stoscheck CM, Florini JR. A rapid fluorometric method for the estimation of DNA in cultured cells. Anal Biochem 1981, 110, 291-294.

19. Lowry OH, Rosebrough NJ, Farr AL, Randall RJ. Protein measurement with the Folin phenol reagent. 7 Biol Chem 1951, 193, 265-275.

20. Early Breast Cancer Trialists' Collaborative Group. Effects of adjuvant tamoxifen and of cytotoxic therapy on mortality in early breast cancer: an overview of 61 randomized trials among 28,896 women. N Engl I Med 1988, 319, 1681-1692.

21. Berry $M$, Metzger D, Chambon P. Role of the two activating domains of the oestrogen receptor in the cell-type and promotercontext dependent agonistic activity of the anti-oestrogen 4-hydroxytamoxifen. EMBO 7 1990, 9, 2811-2818.

22. Pollak MN. Therapeutic implications of growth factor research. In: Ragaz J, ed. High Risk Breast Cancer Therapy. Heidelberg, Springer, 1991, 473-491.

23. Lamberts SWJ, Krenning EP, Klijn JGM, Reubi J-C. Clinical applications of somatostatin analogues. TEM 1990, 1, 139-144.

24. Reubi JC, Waser B, Foekens JA, Klijn JGM, Lamberts SWJ, Laissue J. Somatostatin receptor incidence and distribution in breast cancer using receptor autoradiography: relationship to EGF receptors. Int f Cancer 1990, 46, 416-420.

25. Pollak MN, Polychronakos C, Guyda HJ. Somatostatin analugue SMS 201-995 reduces serum IGF-I levels in patients with neoplasms potentially dependent on IGF-I. Anticancer Res 1989, 9, 889-891.

26. Kleinberg DL, Ruan W, Catanese V, Newman C, Feldman M. Non-lactogenic effects of growth hormone on growth and insulinlike growth factor I messenger ribonucleic acid of rat mammary gland. Endocrinology 1990, 126, 3274-3276.

27. Glimm DR, Baracos VE, Kenelly JJ. Molecular evidence for the presence of growth hormone receptors in the bovine mammary gland. $\mathcal{F}$ Endocrinol 1990, 126, R5-R8.

Acknowledgements - The authors would like to thank ICI Pharmaceuticals for their gift of the tamoxifen citrate, Dr J. Gordon (Montreal Children's Hospital, McGill University) for his help in obtaining the lamb pituitaries, Dr L. Sanford and Ms D. Leggee (Macdonald College, McGill University) for doing the ovine PRL and LH assays, and Ms Sharon Lerner for her technical assistance in the protein and DNA assays. This work was supported by the Medical Research Cuuncil of Canada (C.G.G.) and the Cancer Research Society (M.N.P.). Dr S.A. Malaab is a Postdoctoral Research Fellow of the McGill University-Montreal Children's Hospital Research Institute. This is publication \#92002 from the McGill University-Montreal Children's Hospital Research Institute. 